Volume 1 Number 2 (2021): 48-61

\title{
Batik SMEs In East Java Indonesia: Interrelationship Between Personal Value and Management Skills Towards SMEs Performance in The New Normal Era
}

\author{
Murtianingsih ${ }^{1}$, Ubud Salim ${ }^{1}$, Atim Djazuli' ${ }^{1}$, Sudjatno ${ }^{1}$ \\ ${ }^{1}$ Management Science Doctoral Program, Economic and Business Faculty, Brawijaya University, \\ Indonesia
}

\begin{abstract}
The development of Batik SMEs in East Java shows a sector that is highly affected by the pandemic due to the unpreparedness of SMEs to face the pandemic conditions. The need for encouragement from the government and strengthening this sector so that it can develop again and make a positive contribution to the regional and national economy. Managerial aspects and personal values owned by Batik SMEs in East Java are expected to be a reinforcing factor for SMEs in facing a very dynamic environment. The purpose of this study was to determine the relationship between personal values and management skills on the performance of Batik SMEs during the new normal era in East Java, Indonesia. The data used were obtained through a survey using a questionnaire, which was then analyzed by factor analysis, descriptive statistics, Pearson product-moment correlation, and multiple regression. The results of the study stated that there was no relationship between personal values and performance, and there was no relationship between management skills and the performance of Batik SMEs in East Java, Indonesia. This research does not include external factors of the research variables, namely government policies that can be measured by inflation rates and tax policies, as well as Bank Indonesia credit interest rates. This study uses the variable management skills, personal values, and performance of Batik SMEs in East Java during the normal era, which are products with local cultural features.
\end{abstract}

Keywords: Management skills; personal values; Batik SMEs performance in the new normal era

This is an open access article under the CC-BY-NC license.

\section{INTRODUCTION}

Batik SMEs in East Java is one of the superior products that have competitiveness both in local and foreign markets; the variety of styles produced signifies the distinctiveness of each region that comes from tradition for generations. This was also supported by UNESCO in 2009, which recognized that batik was a cultural heritage that became an icon of the Indonesian nation (Kusrianto, 2013); based on data from the Ministry of Cooperatives and MSMEs, 98 percent of the MSME sector was affected by the pandemic, in 2019 under normal conditions, the contribution of the MSME sector to the gross domestic product was 80 percent, with a labor absorption capacity of more than 90 percent. Batik in the East Java region is the largest SME sector compared to other sectors (accessories and other processed products), various changes occurred during the pandemic, as well as consumer behavior experienced a drastic shift and decline. As one of the superior products, batik can be said to have experienced a decline which has an impact on the income of business actors and batik in the region because people's purchasing power has decreased. Changes that occurred during the pandemic also brought changes to consumer behavior 
Journal of Social Entrepreneurship Theory and Practice (JSETP), Vol. 1 (2), 48-61

Batik SMEs In East Java Indonesia: Interrelationship Between Personal Value and Management Skills

Towards SMEs Performance in The New Normal Era

Murtianingsih, Ubud Salim, Atim Djazuli, Sudjatno

in business transactions; this became the potential for Batik SMEs to respond quickly and respond to changes so that the micro sector could bounce back. This requires the capability of managers or knowledge of managers to be able to compete in a dynamic business environment because the biggest problem in SMEs is their human resources. Referring to the theory of human resources (Martin et al., 2013; Oyedele et al., 2014) argues that entrepreneurs with low human resources can develop through training to increase their knowledge and abilities.

Knowledge management capability is the ability of company managers to manage dynamically based on their knowledge from time to time by reconfiguring and re-aligning the process of knowledge exploration, retention, and exploitation from within and outside the organization (Lichtenthaler and Lichtenthaler, 2009). Perren and Grant (2001) stated in their general view that developing management capabilities needed by SMEs should be based on broad definitions of capability, including being able to accommodate the capabilities needed to manage a business in order to grow. This shows that with the right ability, it can increase company growth, similar to the results of Francis, Asah, et al. (2015), which states that the ability of the managerial has a significant positive effect on the performance of SMEs. But not so with the results of previous studies, which stated that managerial ability does not significantly influence company performance (Shiu, 2006; Clark et al., 2010).

The problem for SMEs is not only in the aspect of managerial ability but also in the personal values possessed by their human resources. In most western countries and other developing countries, personal values greatly impact the success of businesses and SMEs, such as the results of Zainol and Ayadurai (2011), Asah et al. (2015), which states that personal values have a significant positive effect on SME performance. In contrast to the results of previous studies, Mazzarol et al. (2009) did not find a significant relationship between personal values and company performance.

In this study, the relationship between personal values and managerial ability on the performance of Batik SMEs in East Java, Indonesia, will be reviewed because some of the results of previous studies are still inconsistent and because of differences in culture, tradition, and economic structure in each country with criteria for small and medium enterprises which refers to the law of Indonesia concerning MSMEs No. 20 of 2008, the criteria are presented in the following table 1:

Table 1. SMEs Criteria

\begin{tabular}{lcc}
\hline Scale enterprises & Criteria for net worth / Assets per year & Sales / Turnover per year \\
\hline Microbusiness & Max Rp.50 million & Max. Rp.300 million \\
\hline Small business & $>$ Rp.50 mil. - Rp.500 mil. & $>$ Rp.300 mil. - Rp.2.5 billion \\
\hline Medium business $\quad>$ Rp.500 mil. - Rp.10 billion & $>$ Rp.2.5 billion - Rp.50 billion \\
\hline Small business labour: 5 - 19 people & \\
Medium business workforce: 20 - 99 people & \\
\hline
\end{tabular}

Data source: Law No. 20 of 2008 
Journal of Social Entrepreneurship Theory and Practice (JSETP), Vol. 1 (2), 48-61

Batik SMEs In East Java Indonesia: Interrelationship Between Personal Value and Management Skills

Towards SMEs Performance in The New Normal Era

Murtianingsih, Ubud Salim, Atim Djazuli, Sudjatno

Based on table 1 above, the Batik SMEs used in this study are small and medium scale businesses with assets of more than Rp.50 million to Rp.10 billion. The purpose of this study is to determine the relationship between managerial ability and personal values on the performance of Batik SMEs in East Java so that the findings can be used to find factors that can improve the performance of SMEs in East Java, Indonesia.

\section{LITERATURE REVIEW}

\section{Personal Value}

Rotter's (1972) Value-Expectancy Theory explains how values influence choice, determinants, and performance. Personal values are the standards or criteria for evaluating information and testing behavior (Sagiv and Schwartz, 1995), and values are factors that influence management actions and decisions (Gao and Kotey, 2008). Schwartz (1992) conceptualizes personal values as beliefs related to the desired final state or behavior and goes beyond the specific situation in the guidelines for the selection and evaluation of relatively important behaviors and events. Five concepts of personal values according to Schwartz (1992) are 1) Concept or belief; 2) Relating to final desires or behavior; 3) Go beyond special situations; 4) As a guide or evaluation of behavior or events; 5) Ordered by relative interests of each other.

Schwartz (2009) states that the five value concepts above are general, which distinguishes these concepts from other motivational goals lies in the content of the concepts. Personal values also encourage ethical behavior from individuals; ethical behavior in question is honest, kind, respectful, sincere, and has social responsibility (Thakur and Kohli, 2015; Serban, 2015). In contrast to researchers who use the concept of personal values, refer to Junid (2010), where personal values are also found in the teachings of Bushido Samurai, namely: courage, loyalty, honor, hard-working, and discipline. Personal values are the key success factors of personal attitudes, behavior, decision making, corporate actions, and leading individuals in a particular way (Fukukawa et al., 2007). Referring to the Bushido teachings, where courage and hard work are important aspects for business actors to continue to be optimistic and look for alternatives or new ideas so that in the new normal era, businesses can develop again. While referring to the theory of expected value (Rotter, 1972), personal values greatly determine individual actions in making decisions which certainly have an impact on business performance, especially in the highly uncertain COVID-19 pandemic situation.

\section{Managerial Skills}

Alvarez and Busenitz (2001) argue that human resources are unique resources and are the most important assets in running a business. Human resources are also one of the most important factors for achieving business success (Haber and Reichel, 2005). In resource-based theory (RBT), competitive advantage can be achieved through unique resources owned by the company, cannot be imitated, is not easily transferred, and scarcity can provide benefits for the company (Barney, 1991; Collis and Mongomery, 2004). Ganotakis (2010) also uses resource-based theory in explaining the importance of human resources in entrepreneurship in order to achieve a competitive advantage; the resources in question are resources that have the ability to organize companies. In a previous study, Dilani et al. (2006) also found the same result that managerial ability had a significant effect on the performance of SMEs in the U.K., supported by research by 
Journal of Social Entrepreneurship Theory and Practice (JSETP), Vol. 1 (2), 48-61

Batik SMEs In East Java Indonesia: Interrelationship Between Personal Value and Management Skills

Towards SMEs Performance in The New Normal Era

Murtianingsih, Ubud Salim, Atim Djazuli, Sudjatno

Asah and Rungani (2015), who examined SMEs in South Africa, stating that managerial ability had a significant effect on SME performance. In stable economic conditions, several empiricists have stated that managerial ability is an important aspect in achieving business success. COVID 19 gives a multiplier effect on the micro sector and is experiencing a lot of downturns (Aisyah et al., 2020). In order for batik SMEs in East Java to have business resilience and develop again in the new normal era, it is very necessary to have good managerial skills from business actors.

\section{SMEs Performance}

\section{Measuring Business Performance}

Various overviews have been carried out during the COVID-19 pandemic, especially for the micro-business sector, which has been greatly affected by its business performance. Cirera et al. (2020) stated that the business performance of various sectors in developing countries had experienced a slump, especially the micro-business sector, although, in previous years, the sector was a national economic booster. Based on data released by the Indonesian Central Bureau of Statistics, the SME sector was still able to grow 5.3\% during the global economic crisis in 2008 compared to 2020 when various countries experienced the COVID-19 pandemic. Various efforts have been made by the Indonesian government as a step to inhibit the spread of the virus. Corona Virus, but on the other hand, the economy is experiencing a bottleneck due to the social restrictions imposed.

Sampe (2012) argues that SME performance is the ability to achieve predetermined organizational goals, supported by Hamid's research (2017) that human resource factors significantly influence business performance. Research on the performance of SMEs has also been conducted by previous researchers who stated that business performance could be achieved through aspects of human resources, namely managerial ability, motivation, and good personal values $(\mathrm{Wu}, 2008)$. With good quality resources, the performance of the SME sector in the new normal is expected to grow slowly, driven by several government policies through Bank Indonesia to stimulate the micro sector, namely relaxation and restructuring of loans and low-interest rates for the micro sector.

\section{Personal value and performance}

Asah and Rungani (2015) stated that personal value has a significant positive relationship to the performance of SMEs, where the findings are in line with research from Shariff and Peou (2008). Factors that affect business performance and growth include the personal value of the leader or manager who is able to formulate a management strategy for business continuity and development (Penrose, 1959). In line with research conducted by Barney (1991), who postulated resource-based theory states that there is a positive relationship between human resources with certain personal characters with organizational performance. Based on some of these empirical facts, it is still considered relevant to the personal values of SME actors to improve business performance in the new normal era, so the research hypothesis is formulated as follows:

\section{H1: Personal value is significantly correlated with the performance of Batik SMEs}


Journal of Social Entrepreneurship Theory and Practice (JSETP), Vol. 1 (2), 48-61

Batik SMEs In East Java Indonesia: Interrelationship Between Personal Value and Management Skills

Towards SMEs Performance in The New Normal Era

Murtianingsih, Ubud Salim, Atim Djazuli, Sudjatno

Managerial Skills and Performance

To achieve sustainability and competitive advantage, companies need a set of managerial competencies from a leader (Hine, Parker, Ireland; 2010). The same opinion is also found in the results of previous studies, namely that the lack of managerial experience, ability, personal quality is the same as the factors of poor economic conditions that can affect business failure (Martin and Staines, 2008). Pansiri, Jaloni, Tentime, Zelealem (2008) also states that managerial factors are the main factors in achieving business performance. Likewise with Chew et al. (2015) argues that business performance can be achieved through the main capability possessed by the company, namely the ability of its human resources. Yamaori et al. (2020), who conducted research on the micro sector in Japan, stated that the managerial aspect or human resource capability is very important to determine business success. Based on the exposure of the results of previous studies, the hypothesis in this study was formulated as follows:

\section{H2: Managerial skills are significantly correlated to the performance of Batik SMEs}

\section{RESEARCH METHOD}

This study took a quantitative method by collecting data through questionnaires which are distributed directly to the place of business and in associations and interviews to obtain qualitative information with Batik UKM entrepreneurs in the East Java area; the respondents used are business owners or managers who manage the business. Indicator questions in the questionnaire refer to several previous studies (Thakur and Kohli, 2015; Asah and Rungani, 2015; Hine, Parker, Ireland; 2010).

The population of East Java Batik SMEs was obtained from the Department of Cooperatives and SMEs of East Java Province, with the sample selected for research based on the criteria for business circulation in accordance with the law. No. 20 in 2008, there was 119 batik SMEs spread across districts and cities of East Java which had a business turnover of $>50$ million and assets owned to run a business $>300$ million, while the complete questionnaire was filled in 98 which was used in the study. The analytical method used is factor analysis, descriptive statistics, Pearson product-moment correlation, and multiple regression, with the following formulation:

$$
\begin{array}{ll}
\mathrm{r} & =\frac{(X-\bar{X})-(Y-\bar{Y})}{\sqrt{(X-\bar{X})^{2}} \sqrt{Y-\bar{Y})^{2}}} \\
\mathrm{Y} & =\mathrm{a}+\beta \mathrm{X}_{1}+\beta \mathrm{X}_{2}+\mathrm{e}
\end{array}
$$

\section{FINDINGS AND DISCUSSION}

\section{Characteristic Samples}

The sample that meets the criteria in the study is 119 from a total population of 324 Batik SMEs under the guidance of the Department of Cooperatives and SMEs of East Java Province with complete questionnaires filled out is 98 . Of the 119 questionnaires distributed to managers who manage businesses or owners directly obtained questionnaires that meet the requirements to be used as data amounting to 98 or $82.4 \%$.

Characteristics of managers or owners who were respondents in the majority of the study (> 40 - 55 years) or $55.1 \%$, aged (> 55 years) $28.6 \%$, and aged between ( 25 - 40 years) amounted to 
$16,3 \%$ Specifically dominated by women that are $62 \%$ and $38 \%$ men, the next level of business experience in the field of batik hereditary with more than 10 years $69 \%$ and between (5-10 years) $31 \%$, with a partial education level the number of high school graduates is $58 \%$ and $42 \%$ is Bachelor.

Business characteristics, from 98 respondents the majority of $67 \%$ the level of business circulation in one year reached more than Rp. 750 million and the remaining 33\% with a business circulation level of Rp. 500 million - Rp. 750 million This value greatly contributes to the gross domestic income of the East Java region and requires government attention so that the products produced are competitive in the global market.

\section{Descriptive Statistic}

\section{Personal Value}

The personal value variable consists of 5 indicators, namely honesty, trust, responsibility, reputation, hard work. The questionnaires were circulated using a linkert scale of 1 - 5 (strongly disagree - strongly agree). Based on the results of the respondents, the results obtained as shown in table 2 below:

Table 2. Personal value variable description

\begin{tabular}{|c|c|c|c|c|c|c|c|c|c|c|c|}
\hline \multirow[t]{2}{*}{ Indicator } & \multicolumn{2}{|c|}{ STS } & \multicolumn{2}{|c|}{ TS } & \multicolumn{2}{|c|}{ CS } & \multicolumn{2}{|c|}{ S } & \multicolumn{2}{|c|}{ S.S. } & \multirow[t]{2}{*}{ Mean } \\
\hline & $\mathrm{F}$ & $\%$ & $\mathrm{~F}$ & $\%$ & $\mathrm{~F}$ & $\%$ & $\mathrm{~F}$ & $\%$ & $\mathrm{~F}$ & $\%$ & \\
\hline Honesty & 0 & $0 \%$ & 0 & $0 \%$ & 2 & $2 \%$ & 84 & $36 \%$ & 12 & $\mathrm{~L} 2 \%$ & 122 \\
\hline Trust & 0 & $0 \%$ & 0 & $0 \%$ & 1 & $1 \%$ & 70 & $71 \%$ & 27 & $28 \%$ & 163 \\
\hline Responsibility & 0 & $0 \%$ & 0 & $0 \%$ & 0 & $0 \%$ & 80 & $32 \%$ & 18 & $18 \%$ & 071 \\
\hline Reputation & 0 & $0 \%$ & 0 & $0 \%$ & 0 & $0 \%$ & 83 & $35 \%$ & 15 & $15 \%$ & 051 \\
\hline Hard work & 0 & $0 \%$ & 0 & $0 \%$ & 3 & $3 \%$ & 85 & $37 \%$ & 10 & $10 \%$ & 102 \\
\hline
\end{tabular}

Data source: data processed 2020

The personal value in the table shows that the average value is 4.102 , which indicates that the manager or business owner responds to good personal values, with the highest scores being trust, honesty, and hard work. The new normal situation really requires an attitude or behavior to work hard and a high sense of trust or an attitude of optimism.

\section{Managerial Skills}

The results of the questionnaire for the managerial skills variable also use a linkert scale ranging from strongly disagree to strongly agree with indicators which include: business planning, teamwork, relationships, supervision, and innovation. The data obtained from the questionnaires that were circulated are presented in table 3 below: 
Table 3. Managerial skills variable description

\begin{tabular}{lccccccccccc}
\hline \multirow{2}{*}{ Indicator } & \multicolumn{2}{c}{ STS } & \multicolumn{2}{c}{ TS } & \multicolumn{2}{c}{ CS } & \multicolumn{3}{c}{ S } & \multicolumn{3}{c}{ S.S. } & Mean \\
\cline { 2 - 10 } & $\mathrm{F}$ & $\%$ & $\mathrm{~F}$ & $\%$ & $\mathrm{~F}$ & $\%$ & $\mathrm{~F}$ & $\%$ & $\mathrm{~F}$ & $\%$ & \\
\hline $\begin{array}{l}\text { Business } \\
\text { Planning }\end{array}$ & 0 & $0 \%$ & 0 & $0 \%$ & 0 & $0 \%$ & 96 & $98 \%$ & 2 & $2 \%$ & 4.031 \\
\hline Teamwork & 0 & $0 \%$ & 0 & $0 \%$ & 0 & $1 \%$ & 97 & $99 \%$ & 1 & $1 \%$ & 4.031 \\
\hline Relationship & 0 & $0 \%$ & 0 & $0 \%$ & 1 & $1 \%$ & 89 & $91 \%$ & 8 & $8 \%$ & 4.071 \\
\hline Supervise & 0 & $0 \%$ & 0 & $0 \%$ & 0 & $0 \%$ & 94 & $96 \%$ & 4 & $4 \%$ & 4.051 \\
\hline Innovation & 0 & $0 \%$ & 0 & $0 \%$ & 0 & $0 \%$ & 90 & $92 \%$ & 8 & $8 \%$ & 4.061 \\
\hline
\end{tabular}

Data source: data processed 2020

Managerial skills in table 3 show positive responses from respondents with an average value of 4.049, which means that a manager must have abilities such as the 5 indicators used in this study. From the description, it is illustrated that the relationship is a dominant indicator that is needed to develop a business that is experiencing the impact of the current pandemic situation.

\section{Performance}

Performance in this study uses indicators of productivity and sales volume, with responses from respondents presented in table 4 below:

Table 4. Performance variable description

\begin{tabular}{|c|c|c|c|c|c|c|c|c|c|c|c|}
\hline \multirow[t]{2}{*}{ Indicator } & \multicolumn{2}{|c|}{ STS } & \multicolumn{2}{|c|}{ TS } & \multicolumn{2}{|c|}{ CS } & \multicolumn{2}{|c|}{$S$} & \multicolumn{2}{|c|}{ S.S. } & \multirow[t]{2}{*}{ Mean } \\
\hline & $\mathrm{F}$ & $\%$ & $\mathrm{~F}$ & $\%$ & $\mathrm{~F}$ & $\%$ & $\mathrm{~F}$ & $\%$ & $\mathrm{~F}$ & $\%$ & \\
\hline Productivity & 0 & $0 \%$ & 8 & $8 \%$ & 90 & $92 \%$ & 0 & $0 \%$ & 0 & $0 \%$ & 2,090 \\
\hline $\begin{array}{l}\text { Sales } \\
\text { volume }\end{array}$ & 0 & $0 \%$ & 20 & $20 \%$ & 75 & $77 \%$ & 3 & $3 \%$ & 0 & $0 \%$ & 2,098 \\
\hline \multicolumn{11}{|c|}{ Mean variable performance } & 2,094 \\
\hline
\end{tabular}

Data source: data processed 2020

The performance of the Batik SME sector based on table 4 shows that the level of productivity and sales is an insufficient condition or is categorized as not good because the average business actor has decreased productivity. 
Journal of Social Entrepreneurship Theory and Practice (JSETP), Vol. 1 (2), 48-61

Batik SMEs In East Java Indonesia: Interrelationship Between Personal Value and Management Skills

Towards SMEs Performance in The New Normal Era

Murtianingsih, Ubud Salim, Atim Djazuli, Sudjatno

\section{Factor analysis between the variables}

The Pearson correlation used in the study to test the strength and direction of the correlation between personal values, managerial skills, and performance using factor analysis, the Barlett Test of Sphericity (BTS) and Kaiser Meyer-Olkin (KMO) test that has been carried out, the results show that the $(\mathrm{KMO}=0.539>0.5$; $\mathrm{BTS}=556.052$; significance level $=0.000)$ indicates that the sample adequacy is met and there is a correlation between variables. Furthermore, a factor analysis test was carried out, which resulted in five factors with eigenvalues greater than number 1 with a total value of $73.91 \%$ of the total variance indicating the magnitude of the factors formed and the remaining $26.09 \%$ explained by other factors not examined. The five factors formed include personal value, managerial skills, productivity, teamwork, and a business plan; personal value is the most important factor compared to other factors with an eigenvalue of 2.260 and a variance of $18.83 \%$, while the business plan is the smallest factor with an eigenvalue of 1,040 and a variance $8.666 \%$. The rotated component matrix is shown in table 5 below:

Table 5. The rotated factor for personal value, managerial skills, performance

\begin{tabular}{lccccc}
\hline Factor & 1 & 2 & 3 & 4 & 5 \\
\hline Honesty & 0.633 & & & & \\
Trust & 0.487 & & & & \\
Responsibility & 0.502 & & & & \\
Reputation & 0.693 & & & & \\
Hard work & 0.741 & & & & \\
Relationship & & 0.648 & & & \\
Supervise & & 0.324 & & & \\
Innovation & & 0.660 & & & \\
Productivity & & & 0.329 & & \\
Sales & & & 0.668 & & \\
Teamwork & & & & 0.799 & \\
Business Plan & & & & & 0.693 \\
Eigenvalue & 2.260 & 1.748 & 1.233 & 1.110 & 1.040 \\
Percentage of variance & 18.830 & 14.567 & 10.273 & 9.252 & 8.666 \\
\hline
\end{tabular}

Data source: data processed 2020

\section{Personal value and performance}

The Pearson product-moment correlation $(\mathrm{r})$ between personal value and performance variables is -0.119 with a p-value of 0.243 , which indicates that there is a negative but not significant relationship between personal value and performance. Several respondents stated that this pandemic was the most difficult period in their business journey; business actors tried to be optimistic and looked for opportunities to sell their products. But the market response is very slow. This batik business has been carried out for generations and has always maintained customer trust, but the COVID-19 pandemic has drastically changed, and business conditions have deteriorated because most people only focus on health problems. The personal values that we have applied so far have not significantly changed business productivity, and the performance of the majority of batik SMEs has also experienced a decline. 
Journal of Social Entrepreneurship Theory and Practice (JSETP), Vol. 1 (2), 48-61

Batik SMEs In East Java Indonesia: Interrelationship Between Personal Value and Management Skills

Towards SMEs Performance in The New Normal Era

Murtianingsih, Ubud Salim, Atim Djazuli, Sudjatno

The results of the study do not support the research (Asah and Rungani, 2015; Shariff and Peou, 2008; Yaakob et al., 2014). The results of multiple regression with the independent variable personal value show the value of $R=0.126, R 2=0.016$ with a significance of 0.222 more than 0.05 , indicating that personal value has no effect on performance, in line with research by Shiu (2006) and Mazzarol et al., (2009) who argue that there is no significant relationship between personal values and business performance of the SME sector. Because business congestion in the SME sector is the impact of the pandemic experienced by many countries

\section{Managerial skills and performance}

The Pearson product-moment correlation $(\mathrm{r}$ ) between managerial skills and performance variables is 0.011 with a p-value of 0.916 , which indicates that there is a positive but not significant relationship between managerial skills and performance, which this study supports (Shiu, 2006; Clark et al., 2010). The results of multiple regressions in table 7 with a t-count value of 0.393 are smaller than the t-table value of 1.980 and a significance level of 0.695 more than 0.05 , stating that managerial skills have no significant effect on performance, the results of this study are inconsistent with research (Appuhami, 2007; Asah \& Rungani, 2015), dynamic management skills are needed in an uncertain situation. a manager must have sensitivity to the conditions that are happening so that the managed business can grow back from adversity (Jose Carlos, 2011).

Batik UKM actors try to innovate and look for opportunities so that the business they run can survive adversity. However, the main problem at this time is the very slow absorption of the market due to the very low purchasing power of the people. The search results of the Central Bureau of Statistics in 2020 show that the East Java economy experienced a regional decline in the second quarter, where it contracted 5.90\% compared to the second quarter of 2019 (https://www.bps.go.id). The biggest problem faced by almost all small business sectors is slowing sales; this is also triggered by the Indonesian government's policy to minimize the spread of COVID 19. Various policies implemented are Large-Scale Social Restrictions (PSBB), Work from Home (WFH), School from Home (SFH). This led to a decline in the community mobility index and resulted in a slowdown in economic activity. In very uncertain conditions like today, good managerial skills are still needed so that the business they run has business resistance and recovers slowly.

Table 6. The Pearson Correlation between personal value, managerial skills, and performance

\begin{tabular}{llrrr}
\hline & & \multicolumn{3}{c}{ Managerial } \\
& & Personal value & skill & Performance \\
\hline Personal value & Pearson Correlation & 1 & $.236^{*}$ & -.119 \\
& Sig. (2-tailed) & & .019 & .243 \\
& $\mathrm{~N}$ & 98 & 98 & 98 \\
\hline Managerial skill & Pearson Correlation & $.236^{*}$ & 1 & .011 \\
& Sig. (2-tailed) & .019 & & .916 \\
& $\mathrm{~N}$ & 98 & 98 & 98 \\
\hline Performance & Pearson Correlation & -.119 & .011 & 1 \\
& Sig. (2-tailed) & .243 & .916 & \\
& $\mathrm{~N}$ & 98 & 98 & 98 \\
\hline
\end{tabular}


Journal of Social Entrepreneurship Theory and Practice (JSETP), Vol. 1 (2), 48-61

Batik SMEs In East Java Indonesia: Interrelationship Between Personal Value and Management Skills

Towards SMEs Performance in The New Normal Era

Murtianingsih, Ubud Salim, Atim Djazuli, Sudjatno

*. Correlation is significant at the 0.05 level (2-tailed).

Table 7. Coefficient Regression

\begin{tabular}{|c|c|c|c|c|c|c|}
\hline \multirow[b]{2}{*}{ Model } & & \multicolumn{2}{|c|}{ Unstandardized Coefficients } & \multirow{2}{*}{$\begin{array}{c}\begin{array}{c}\text { Standardized } \\
\text { Coefficients }\end{array} \\
\text { Beta } \\
\end{array}$} & \multirow[b]{2}{*}{$\mathrm{t}$} & \multirow[b]{2}{*}{ Sig. } \\
\hline & & B & Std. Error & & & \\
\hline \multirow[t]{3}{*}{1} & (Constant) & 389.205 & 171.506 & & 2.269 & .026 \\
\hline & Personal value & -.384 & .312 & -.129 & -1.230 & .222 \\
\hline & Managerial skill & .145 & .368 & .041 & .393 & .695 \\
\hline
\end{tabular}

a. Dependent Variable: Performance

Table 8. Impact of COVID 19 on Business Performance: quotation from respondents

\begin{tabular}{|c|c|}
\hline Respondent & General impact \\
\hline $\begin{array}{l}\text { R1 R3 R4 R12 R25 R58 R70 } \\
\text { R112 }\end{array}$ & The pandemic has stopped my business, and my revenues \\
\hline $\begin{array}{l}\text { R2 R5 R6 R16 R23 R66 R92 } \\
\text { R110 R118 }\end{array}$ & Many of my customers can't afford to pay \\
\hline $\begin{array}{l}\text { R7 R13 R24 R35 R59 R71 R93 } \\
\text { R94 R109 R117 }\end{array}$ & I hope my business can rise, \\
\hline R8 R10 R11 R28 R33 R72 R95 & I feel so failed, even though I try to innovate \\
\hline R9 R14 R20 R34 R36 R69 R89 & I can't afford working capital credit installments \\
\hline R15 R17 R26 R37 R44 R80 & I hope there is a better chance \\
\hline $\begin{array}{l}\text { R18 R21 R30 R39 R52 R73 R88 } \\
\text { R96 R101 }\end{array}$ & $\begin{array}{l}\text { The pandemic makes the market response very slow; } \\
\text { everyone is only focused on health problems. }\end{array}$ \\
\hline $\begin{array}{l}\text { R19 R22 R31 R42 R51 R81 } \\
\text { R105 R115 }\end{array}$ & Huge negative impact on sales \\
\hline R27 R29 R32 R38 R41 R97 & Pandemic has increased our cost and reduced our income \\
\hline $\begin{array}{l}\text { R40 R43 R48 R61 R77 R87 } \\
\text { R114 }\end{array}$ & I have to change my strategy and prepare a business plan \\
\hline R45 R49 R54 R63 R67 R91 & It is also an obstacle for my marketing activities \\
\hline
\end{tabular}


Journal of Social Entrepreneurship Theory and Practice (JSETP), Vol. 1 (2), 48-61

Batik SMEs In East Java Indonesia: Interrelationship Between Personal Value and Management Skills

Towards SMEs Performance in The New Normal Era

Murtianingsih, Ubud Salim, Atim Djazuli, Sudjatno

\begin{tabular}{ll}
\hline R46 R53 R56 R57 R86 R99 & I thought pessimistically and didn't know what to do \\
R106 R11 R116 & \\
\hline R47 R50 R62 R76 R82 R102 & This is the most difficult time in my business journey \\
R119 & \\
\hline R55 R65 R68 R85 R92 R107 & Profit and demand curves have both been going downhill \\
\hline R60 R75 R79 R83 R98 R108 & My product is very stuck in the market \\
\hline R64 R74 R78 R84 R103 & I am having financial difficulties continuing my business \\
\hline R90 R100 R104 R113 & I terminated some of my employees
\end{tabular}

Data source: Direct interview with respondents

\section{CONCLUSION}

The results of hypothesis testing in this study indicate that there is no significant relationship between personal values and managerial skills with the performance of Batik SMEs in East Java because the performance of Batik SMEs during this pandemic is a sector that is affected and has decreased performance. The results of direct interviews with respondents indicate that business performance is experiencing a slump (Table 8). Based on this situation, it is still necessary to develop good management skills and personal values so that batik SMEs are more prepared in the current business climate and can develop again because batik still has good potential. Paying attention to people's behavior as consumers is an important thing that must be considered so that SMEs can bounce back (Aisyah et al., 2020); as stated by Asah et al. (2015) that SMEs need personal values from their managers. Dan Chew et al. (2015) also stated that SMEs would be successful if the managers also had good managerial skills. Limitations in this study do not include external factors in measuring the performance of SMEs, namely government policies in the micro-business sector and bank interest rates which greatly impact business operations. Suggestions for further research are to measure the performance of micro-enterprises also need to include external factors as a determinant of performance.

\section{ACKNOWLEDGMENT}

I would like to thank some people who helped me complete this article, provided direction and motivation; Ubud Salim, Atim Djazuli, and Sudjatno, as well as the head of the study program for the doctoral program in management science, Universitas Brawijaya Noermiati.

\section{REFERENCES}

Aisyah, Aminy, Kartika Fitriasari, Dinas Koperasi dan UMKM Propinsi Jawa Timur, (2020), "Analysis of the impact of Covid 19 for SMEs in East Java Indonesia", Conference. Pdf [Article \% 20 Text.2203-2-10] 
Journal of Social Entrepreneurship Theory and Practice (JSETP), Vol. 1 (2), 48-61

Batik SMEs In East Java Indonesia: Interrelationship Between Personal Value and Management Skills

Towards SMEs Performance in The New Normal Era

Murtianingsih, Ubud Salim, Atim Djazuli, Sudjatno

Alvarez, S. and Busenitz, L., (2001), " The entrepreneurship of resource- based theory”, Journal of Management, Vol. 27 No. 6, pp. 755-775.

Appuhami, R., (2007), "The impact of intellectual capital on investors capital gain on shares: an empirical investigation of Thai banking, finance, and insurance sector", International Management Review, Vol. 3 No.2, pp. 14-25.

Asah, Francis and Ellen Rungani., (2015). "The Impact of Motivations , Personal Values and Management Skills on the Performance of SMEs in South Africa." African Journal of Economic and Management Studies 6(3):308-22.

Barney, J. B., (1991), Firm Resources and Sustained Competitive Advantage, Journal of Management 17(1) : 99-120.

Chew, David A. S. et al., (2015). "Core Capability and Competitive Strategy for Construction SMEs in China." Chinese Management Studies 2(3):203-14.

Cinera, X., M.Cruz, E. Davies. Grover, L. Lacovone, J. E. Lopezz, D. Medvedev, F. O. Maduko, G. Navyar, S. R. Ortega and J. Torres, 2020, " Policies to support Business through the Covid 19 Shock : A Firm level prespective", Covid Economic, 64.

Collis, David dan Montgomery, Cynthia., (2004), Corporate Strategy : A Resource Based Approach, 2nd Edition, Irwin McGraw-Hill, Boston.

Clarke, M., Seng, D. Whiting, R.H., (2010), "Intellectual capital and firm performance in Australi", available at :http://otago.ourachive.ac.nz (accessed 19 December 2019).

Dilani Jayawarna, Allan Macpherson, Alison, Wilson., (2006), “Managers' perception of management development needs of manufacturing SMEs", education +Training, Vol. 48 Issue :8/9, pp. 666-681.

Fukukawa, K. Shafer, W.E. and Lee, G.M. (2007), "Values and attitude towards social and enviromental accountability: a study of of MBA students", Journal of Business Ethics. Vol. 71, No. 4, pp. 381-394.

Ganotakis P., (2010),"Founder's human capital and the performance of Uk new technology based firms", Small Business Economics, Vol. 35 No. 4, pp. 1-21

Gao, K. and Kotey, B., (2008),"Chinese values and SME Strategy in the Chinese economic transition : how close are they to the west?" International council for small business world conference, Halifax Nova Scotia, 22-25 June.

Haber, S. and Reichel, A., (2005), "Identifing meausures of small ventures-the case of the tourism industry”, Journal of Small Business Management, Vol. 43 No. 3, pp. 257-286.

Hamid, Zeeshan., (2017). "Impact Of High-Performance Work Systems On Export-Oriented Smes Performance: The Mediating Role Of Human Capital Development." 11(2):142-64.

Hine, D. C., Parker, R., and Ireland. D., (2010), The knowledge exchange intermediary as service provider, A discussion and an Australian case, The service industry Journal, 30 (5), 713-729.

Jose Carlos, M. N., Pinho, (2011), Social capital and dynamic capabilities in international performance of SMEs, Journal of Strategy Management, Vol.4 No. 4, pp. 404-421.

Junid, S., (2010), "Modal dan Keuangan Usahawan Melayu, Pelaksanaan Program Ekonomi Inovatif dan Pragmatik : Cadaangan Perubuhan BMEB (Bank Mode Ekonomi Baru / Bank I Malaysia) Kertas Kerja a3, Konvensyen Usahawan Melayu, NGO Force ke 3 Penjana Ekonomi Banagsa, Kuala Lumpur. 
Journal of Social Entrepreneurship Theory and Practice (JSETP), Vol. 1 (2), 48-61

Batik SMEs In East Java Indonesia: Interrelationship Between Personal Value and Management Skills

Towards SMEs Performance in The New Normal Era

Murtianingsih, Ubud Salim, Atim Djazuli, Sudjatno

Kusrianto, Adi., (2013), “Batik : Filosofi Motif dan Kegunaan. Yogyakarta. Penerbit Andi

Lichtenthaler, U. and Lichtenthaler, E. (2009), "Capability based framework for open innovation : Complementing absorptive capasity", Journal of Management Studies, Vol.46. No. 8, pp. 1315-1338.

Martin, C.B., McNally, J.J., \& Kay, M.J., (2013), Examining the formation of human capital in entrepreneurship : a meta-analysis of entrepreneurship education outcomes, Journal of Business Venturing, 28 (2), 211-224.

Martin, G. and Staines, H., (2008). Managerial competencies in small firm. Available at: www. Emeraldinsight. Com/insight/viewcontentitem.do?.contenttype (accessed 7 May 2020)

Mazzarol, T., Reboud, S. and Soutar, G.N., (2009), "Strategic planning in growth oriented small firms", International Journal of Entrepreneurial Behavior \& Research, Vol. 15 NO. 4, pp.330-355.

Oyedele, M.O., Oluseyi, O., Olalekan, A., Kabuoh, M., and Elemo, G.N., (2014) on Entrepreneurial success of small and medium enterprises (SMEs) :"A Conceptual and Theoritical framework", Journal of Economics and sustainable development, ISSN 2222-1700 (paper), ISSN 2222-2855 (online), Vol. 5 No. 16.

Pansiri, Jaloni; Tentime, Zelealem, T., (2008). "Assessing Managerial Skills in SMEs for Capacity Building." Journal of Management Development 27(2):251-60.

Pemerintah Republik Indonesia, Unsang-Undang No. 20 Tahun (2008) tentang Usaha Kecil, Mikro, dan Menengah.

Perren, L. and Grant, P., (2001), Management and Leadership in U.K. SMEs : Witness testimonies from the word of entrepreneurs and SME Managers, The Excellence in Management and Leadership, London.

Penrose, E.T., The theory of the growth of the firm, 3rd edition, USA : Oxford University Press, 1959.

Rotter, J.B., (1972),"An introduction to social learning theory", in Rotter, J.B., Chance, J.E., and Phares, E.J., (Eds), Application of Social Learning Theory of Personality, Holt, Rinehart and Winston, New York, NY, pp.134-141.

Sagiv, L., and Schwartz, S., (1995), "Value priorities and readiness for out-group social contact", Journal of personality and social psychology, vol. 69 No.3, p.437.

Sampe, F., (2012). The influence of organizational learning on performance in Indonesian SMEs. PhD thesis. Southern Cross University. Lismore. NSW.

Schwartz, S. H., (1992), "Universals in the content and structure of value : Theoritical advances and empirical test in 20 countries", Advances in experimental social psychology, Vol. 25, pp.1-65.

Schwartz, S. H., (2009), "Basic human values", paper presented at the cross-National comparison seminar on the quality and comparability of measures for construct in comparative research : Methods and Applications, Bolzano.

Serban, A. D., (2015), "How Personal Values Influence Romanaian CSR Managers Involvement in CSR Campaigns", Management Dynamics in the Knowledge Economy, Vol. 3 No. 4, pp 729-748.

Shariff, M. N. M., and Peou, C., (2008), "The relationship entrepreneurial values, firm financing and the management and growth performance of SMEs in Cambodia", Problems and perspectives in Management, Vol. 6 No. 4, pp. 55-64.

60 
Shiu, H.J., (2006), "The application of the value added intellectual coefficinet to measure corporate performance : evidence from technological firms", International Journal of Management, Vol. 23 No. 2, pp. 356-365.

Thakur, A. and Kohli, S., (2015). Relationship between personal values and perception towards corporate social responsibility : a critical review. IJABER, Vol. 13 No. 3, pp. 997-1003.

Wu. W., (2008). Dimensions of social capital and firm competitiveness improvement : the mediating role of information sharing. Journal of Management Studies, Vol. 45 No. 1, pp. 122-146.

Yaakob, N., Mahmood, R., Zin, M.S., \& Puteh, M., (2014), "Factors affecting the performance of small business start-ups under Tunas Mekar Programme", in the proceedings of the ASEAN Entrepreneurship Conference", Available at http://link.Springer.com/book/10.1007/978-981-100036-2.

Yamori, N. and T. Aizawa, (2020), "The impact of the first wave of the COVID 19 crisis on small and medium-sized enterprises nd credit Guraantee Responses: earlier lessons from Japan, CVID Economic, 63.

Zainol, F.N. and Ayadurai, S., (2011), "Entrepreneurial orientation and firm performance : the role of personality traits in family firms in Malaysia", International Journal of Business and Social Science,Vol.2 No. 1, pp. 59-71. 